\title{
The capacity of formative assessment in teaching mathematics in primary schools by students: Analytical results from 11 universities in Vietnam
}

Trinh Tuyet Thi Le, Dong Thap University, Dong Thap, Vietnam, letrinh1282@gmail.com ORCID: 00000003-3970-9773

Chung Xuan Pham, Vinh University, Nghe An, Vietnam; phamxuanchung77@gmail.com ORCID: 00000002-9785-1957

Son Trieu Nguyen, Tay Bac University; Son La, Vietnam; trieuson@utb.edu.vn ORCID: 0000-0002-04697453

Trung Tran1, Vietnam Academy for Ethnic Minorities, Hanoi, Vietnam; trungt1978@gmail.com ORCID: 0000-0002-0459-7284

\begin{abstract}
In Vietnam, many pedagogical students after graduating from their universities have good teaching capacity but their capacity to assess learners, especially the capacity of formative assessment has not met the requirements asset. This article aims to analyze the formative assessment capacity in teaching primary mathematics of pedagogical students at universities in Vietnam. The results of quantitative data analysis from a survey of 579 students juniors and seniors with a major in primary education at 11 universities in Vietnam showed their formative assessment capacity in teaching primary mathematics at universities in Vietnam is limited. From the results, we propose measures to develop formative assessment capacity in teaching primary mathematics of students
\end{abstract}

Keywords: Formative assessment, Pedagogical students, Teaching primary Mathematics

Received: 23.05 .2020

Accepted: 03.08.2020

Published: 01.12.2020

\section{INTRODUCTION}

In Vietnam, the general education curriculum changed in 2018 poses teaching innovation requirements that focus on developing learners' capacity, with a focus on integrated and differentiated teaching, paying special attention to slow pupils in teaching process(Tran, Nguyen, et al., 2019); Application of information technology to teaching in general schools such as mobile learning applications in teaching(Phuong Thao et al., 2019), using E-Class education model in teaching(Tran et al., 2020), focusing on teaching activities through STEM-oriented experience(Tran, Le, et al., 2019).

The primary level is an important one in the general education curriculum, mathematics for this primary level is the foundation subject to help pupils form thinking and calculation to be able to study well at higher levels and study better than other science subjects (Dinh, 2016). Reforming Vietnam's general education curriculum in 2018 poses many challenges for primary teachers in renovating contents, forms, and methods of teaching as well as testing and assessing results of mathematics learning of primary-school pupils, in addition to innovating methods of teaching primary mathematics, the renovation of primary pupil assessment activities needs to be paid special attention to ensure compliance with the psychophysiological characteristics of primary-school pupils. For the primary level, the assessment often focuses on the learning process rather than the overall assessment to help teachers timely help and straighten students in the learning process(Hoa, 2012). Therefore, primary teachers need to have full capacity to assess the process of teaching in general and teaching mathematics in particular for primaryschool pupils to achieve the highest level of assessment purpose(Hop, 2015).

The training of pedagogical students at universities is closely linked to the general education curriculum because the process of pedagogical training for bachelor's degree at higher education level is the process of preparing knowledge and skills for pedagogical students

\footnotetext{
${ }^{1}$ Corresponding author: trungt1978@gmail.com; Tel.: +84-9133-73656 (T.T.)
} 
to meet output standards for general teachers(Chung, 2012). The changed general education curriculum sets intensive renovation requirements for Vietnamese higher education in the training management process to ensure the quality requirements in teacher training in order to meet effectively new needs and create a sustainable educational environment(Pham et al., 2019). The process of training primary education students at universities is the process of rehearsing teaching methods of primary knowledge and testing \& assessing in teaching primary education for students before graduation to practice. However, students with a major in primary education in Vietnam have been trained on teaching methods at the primary level $\mathrm{Cu}$ Quoc Chung et al., 2005) but they have little practice in assessment skills in teaching primary education at universities(Trinh, 2013). Therefore, the problem posed is that universities need to accurately determine the teaching capacity as well as the assessment capacity of students compared with the output standards in order to plan for fostering assessment capacity for primary education students in order to meet the requirements of reforming the general education curriculum.

\section{MATERIALS AND METHODS}

\section{Formative assessment in teaching primary mathematics}

Assessment and teaching are closely related, the assessment is both independent reflect of teaching process and final stage of the teaching process. In the process of teaching, teaching, learning and assessing are three activities which often occur simultaneously and have a close impact on each other, so each teacher must research to choose assessment methods for compliance with the purpose of teaching and effects of such assessment on future plans for pupils.(Bourke \& Mentis, 2014). The assessment is a process by which information obtained is related to a number of goals or known and assessed goals to assess whether the goal has been achieved. The assessment includes assessing knowledge and skills, and understanding; assessing knowledge and skills is often simpler because there are often criteria to achieve or not, assessing knowledge is more difficult because it is difficult to measure, because the criteria will be more difficult to explicitness(Kizlik, 2012).

The assessment has three types: diagnostic assessment (a form of pre-assessment to preliminarily diagnose learners' capacity including knowledge, competencies and attitudes of learners to help adjust the teaching process in accordance with objects); Summative assessment (a form of assessment after finishing a part of knowledge to capture learning results of learners often used to classify learners); formative assessment ( an assessment implemented during the teaching process to help teachers and learners collect quick feedback on the quality and capacity of learners to timely adjust teaching and learning in order to improve learning results of pupils(Khanh, 2004).

Assessing pupils will be a challenge for teachers whether they are beginner teachers or teachers who are experienced by the requirement of time and effort invested in conducting an assessment activity (Sainsbury \& Benton, 2011). However, the assessment of learners is still indispensable in the teaching process, conducted regularly and continuously throughout the teaching process, so teachers are required to think daily to choose assessment methods in order to match lesson goals and the characteristics of pupils, teachers always have to ask questions including: What are assessment purpose? Who is the object of assessment and who is the assessment result for? How is the assessment conducted? and answering such questions, teachers have enough background on assessment and assessment implementation in the teaching process. (Bourke \& Mentis, 2014).

Comparing among types of assessment show that the diagnostic assessment at the beginning of a course provides information about pupils at the beginning time (Cook, 2001). The summative assessment does not have sufficient comprehensiveness to pupils' learning process, the formative assessment is conducted during the teaching process, such formative assessment is helpful in improving learning or teaching while it is still taking place. The formative assessment, in essence, motivates educators to respond more quickly to pupils' learning in an educational experience (Garrett \& Camper, 2015). In fact, a good teacher should use both types of assessment, summative assessment and formative assessment during his/ her 
teaching process. The summative assessment often includes assessments of what learners have learned over a specified period of time. When the summative assessment prevails in teachers' work, it can happen that during the final exam, or test, etc., teachers found that learners understood the topic of teaching in a completely different way from what teachers expected. In order to overcome and prevent this, teachers can use a formative assessment focusing on learners' needs. Information obtained in such a way helps teachers plan and further improve their instruction. Teachers assess not only learners' progress but also their own teaching situation. This type of assessment is predicted to correspond with the current trends in the learners' assessment. The assessment model focuses on learners 'errors that were dropped and the attention is turned to learners' advantage and development (Marks, 2015). Three types of assessments are needed in teaching, but at primary level, the formative assessment is valued because the assessment focuses on observing the behavior of primary pupils, commenting and assessing results of primary-school pupils, thereby orienting pupils for better learning results (Hop, 2015).

The formative assessment, whether associated with its name or not, is always found in the classrooms. We can see that good teaching is inseparable from good assessment and vice versa. The teaching and assessment process is carried out in a circular manner including teaching, assessment, assessment of teaching, re-teaching (if necessary), assessment and teaching, etc.(Barry J. Zimmerman, 1990). A formative assessment is an assessment of pupil achievement in the learning process to inform teachers and pupils about what pupils have achieved in the teaching process, thereby help learners to outline next action plan of the learning process and help teachers timely adjust teaching activities in accordance with teaching goals(Dinh, 2016).

The formative assessment includes several factors: Recognizing the right purpose of the assessment derived from teaching purposes; determining right steps in the assessment of pupils' knowledge acquisition results; building standard exercises as a basis for assessment; establishing appropriate forms of assessment (Pryor, 2004). Therefore, in order to make a good assessment, a rigorous process must be followed to ensure objectivity, accuracy and fairness for learners. The formative assessment helps pupils appreciate standards expected from them, there are many methods that assessors used for formative assessment in teaching such as doing exercises, answering questions or performing a task(Yorke, 2003). In addition, the formative assessment has generated significant interest and research into promoting pupils' responsibility for their own learning results (Andrade \& J.Cizel, 2013).

The formative assessment is most effective when used as a response instrument for participants including teachers, pupils, and students' families who are interested in the results, thereby the formative assessment contributes to improving the quality of education because this type of assessment often focuses on assessing the learning and developing needs of pupils who are involved in the learning process(Garrett \& Camper, 2015). The formative assessment brings many benefits to learners such as providing and timely giving feedback on the learners' learning situation; responding quickly to learning results and easily handling learning results, thereby adjusting methods and formats to meet the concerns and needs of teachers and pupils and positively impacting the learning process (Marks, 2015).

In the formative assessments, pupils can use assessment results to accelerate their learning because the important feature of this type of assessment is timely give feedback to pupils during the learning process to help them improve their learning results, however, in order to effectively respond to learning, teachers must give early results(Fiza Rashid-Doubell, Robin O' Sullivan, 2017). The formative assessment should be conducted early in the learning process to ensure the effective improvement of learning result, instruments with appropriately design for formative assessment will obtain pupil information during the process of answering questions (Kibble, 2007).

The results of the formative assessment can be classified into three categories: Getting good results in the first time; not getting good results in the first time and assessing repeatedly whether the first time achieved a good result or not. Successful pupils are continued to be observed through their scores without guidance, pupils in the group who did not pass in the first time, teachers will advise on further learning and discussion skills continuously during 
learning process to identify and improve learning skill weaknesses, along with action plans to help pupils master basic knowledge (knowledge, recollecting, taking tests). The third group is more closely researched, teachers often help and create learning groups to help slow pupils grasp promptly in the learning process (Fiza Rashid-Doubell, Robin O' Sullivan, 2017). Therefore, in formative assessment, the key issue is that how well the teacher understands about the formative assessment? How to choose assessment forms and instruments? How to collect data and analyze and respond assessment information? Therefore, in the formative assessment, the key issue is the capacity assess Mathematics in teaching of pedagogical students at universities, including the capacity to plan for assessing learning results; the capacity to building assessment and selection criteria , building assessment tools; the capacity to organize activities to collect information; the capacity to use information collection instruments; the capacity to search and select information from data suitable for the purpose of the assessment; the capacity to use information processing methods; the capacity to identify impacts and causes of the current situation; the capacity of information storage; the capacity to communicate assessment results to different objects; the capacity to use assessment results to adjust the teaching process; the capacity to give self-comment and re-adjust the assessment process(Chung, 2012).

However, at the primary level, when implementing the formative assessment, attention should be paid to the characteristics of primary-school pupils. The formative assessment in teaching mathematics in primary schools is a type of assessment done regularly throughout the process of learning primary mathematics and other educational activities, including the process of applying knowledge, skills in primary schools, families and communities, collecting feedback on results of learning primary mathematics of pupils to support, timely adjust, promote their progress of learning(Dinh, 2016). The formative assessment in teaching mathematics in primary schools can use forms such as using objective test questions(Hop, 2015); task assignment form for pupils(Pham Dinh Thuc, 2007); observing pupils' behavior and making comments(Tho, 2014). It can be seen that it is necessary to prepare students with major in primary education for formative assessment capacities so that they have sufficient knowledge, skills and proper attitude in organizing formative assessment in teaching primary mathematics, in which, in Vietnam, students can practice with three methods of formative assessment in teaching mathematics including:

- Assessing by multiple-choice questions

- Assessing by task assignment form

- Assessing by observing behavior

The capacity of formative assessment in teaching primary mathematics by students is based on the teachers' assessment capacity, including (1) Understanding of testing and assessment; (2) Implementation of testing and assessment (Teacher, 2005), as described in Table 1.

\section{Research methodology}

This research aims to analyze the current situation on students' capacity of formative assessment in teaching Mathematics in primary schools, thereby proposing recommendations and measures to help develop the capacity of formative assessment in teaching Mathematics for students with major in primary education at Vietnamese universities.

\section{Research instrument}

Based on the theoretical framework of formative assessment capacity components in teaching Mathematics by students in Table 1, in order to be able to assess the capacity of formative assessment in teaching Mathematics in primary schools by students, the research has reviewed related documents and used focus group discussions with students majoring in primary education and lecturers from 11 Vietnamese universities. In focus group discussions, participants were provided with a theoretical framework of formative assessment capacity in teaching primary Mathematics. The agreement of the discussion group has determined that 
there are six factors shown in Figure 1 and corresponding to the 25 observed variables identified (Table 2).

Table 1. Theoretical framework on components and criteria of behavior and capacity for formative assessment of students in teaching mathematics in primary schools

\begin{tabular}{|c|c|c|c|}
\hline No & $\begin{array}{l}\text { Component of } \\
\text { formative } \\
\text { assessment } \\
\text { capacity }\end{array}$ & $\begin{array}{l}\text { Description of } \\
\text { expression of } \\
\text { capacity } \\
\text { component }\end{array}$ & Description of behavioral index \\
\hline \multirow[t]{6}{*}{1} & \multirow[t]{6}{*}{$\begin{array}{l}\text { Understanding } \\
\text { of formative } \\
\text { assessment }\end{array}$} & \multirow{3}{*}{$\begin{array}{l}\text { Demonstrate an } \\
\text { understanding of } \\
\text { methods, forms, and } \\
\text { instruments for } \\
\text { formative } \\
\text { assessment in } \\
\text { teaching primary } \\
\text { mathematics }\end{array}$} & $\begin{array}{l}\text { Level 1. Select methods, forms and develop formative } \\
\text { assessment instruments suitable to the goals of } \\
\text { teaching primary mathematics. }\end{array}$ \\
\hline & & & $\begin{array}{l}\text { Level 2. Coordinate using a variety of methods and } \\
\text { forms of formative assessment appropriate to the } \\
\text { characteristics of mathematics and primary-school } \\
\text { pupils }\end{array}$ \\
\hline & & & $\begin{array}{l}\text { Level 3. Have an appropriate formative assessment } \\
\text { strategy for primary-school pupils to actively } \\
\text { participate in the assessment process. }\end{array}$ \\
\hline & & \multirow{3}{*}{$\begin{array}{l}\text { Demonstrate an } \\
\text { understanding of } \\
\text { how to use formative } \\
\text { assessment results in } \\
\text { teaching and } \\
\text { education }\end{array}$} & $\begin{array}{l}\text { Level } 1 \text {. Select the form of responding results from the } \\
\text { formative assessment that is appropriate for primary- } \\
\text { school pupils, their parents (or guardians) and schools. }\end{array}$ \\
\hline & & & $\begin{array}{l}\text { Level 2. Have plans to use the results of the formative } \\
\text { assessment for the purposes of developing the quality } \\
\text { and competency of primary-school pupils. }\end{array}$ \\
\hline & & & $\begin{array}{l}\text { Level } 3 \text {. Share knowledge of methods, form of formative } \\
\text { assessment and responding method with other } \\
\text { students }\end{array}$ \\
\hline \multirow[t]{6}{*}{2} & \multirow[t]{6}{*}{$\begin{array}{l}\text { Implementation } \\
\text { of testing and } \\
\text { assessment }\end{array}$} & \multirow{3}{*}{$\begin{array}{l}\text { Develop a formative } \\
\text { assessment plan to } \\
\text { ensure openness, } \\
\text { objectivity, accuracy, } \\
\text { comprehensiveness } \\
\text { and fairness. }\end{array}$} & $\begin{array}{l}\text { Level } 1 \text {. Develop formative assessment plans that is } \\
\text { suitable to teaching plans and mathematics curriculum } \\
\text { at primary level. }\end{array}$ \\
\hline & & & $\begin{array}{l}\text { Level 2. The formative assessment plan uses methods } \\
\text { and forms of assessment suitable to the characteristics } \\
\text { of primary mathematics, primary school pupils and } \\
\text { assessment purposes. }\end{array}$ \\
\hline & & & $\begin{array}{l}\text { Level } 3 \text {. The formative assessment plan shows methods } \\
\text { and forms of assessing pupils based on approaching to } \\
\text { mathematics learning competence. }\end{array}$ \\
\hline & & \multirow{3}{*}{$\begin{array}{l}\text { Organize practice of } \\
\text { formative } \\
\text { assessment in } \\
\text { teaching primary } \\
\text { mathematics }\end{array}$} & $\begin{array}{l}\text { Level 1. Organize the formative assessment to ensure } \\
\text { the content and form in accordance with the } \\
\text { established plan }\end{array}$ \\
\hline & & & $\begin{array}{l}\text { Level } 2 \text {. Organize the formative assessment in a flexible } \\
\text { way but remain its openness, objectivity, accuracy, } \\
\text { comprehensiveness and fairness. }\end{array}$ \\
\hline & & & $\begin{array}{l}\text { Level 3. Coordinate and share with others about the } \\
\text { formative assessment activities during the internship } \\
\text { process, and coordinate to organize the formative } \\
\text { assessment in a flexible way with ensuring openness, } \\
\text { objectivity, accuracy, comprehensiveness and fairness. }\end{array}$ \\
\hline
\end{tabular}


Table 1. Continued.

\begin{tabular}{|c|c|c|c|}
\hline No & $\begin{array}{l}\text { Component of } \\
\text { formative } \\
\text { assessment } \\
\text { capacity }\end{array}$ & $\begin{array}{l}\text { Description of } \\
\text { expression of } \\
\text { capacity } \\
\text { component }\end{array}$ & Description of behavioral index \\
\hline \multirow[t]{6}{*}{2} & \multirow[t]{6}{*}{$\begin{array}{l}\text { Implementation } \\
\text { of testing and } \\
\text { assessment }\end{array}$} & \multirow{3}{*}{$\begin{array}{l}\text { Use information } \\
\text { technology to } \\
\text { support formative } \\
\text { assessment in } \\
\text { teaching primary } \\
\text { mathematics }\end{array}$} & $\begin{array}{l}\text { Level } 1 . \text { Be able to use software and technical } \\
\text { facilities to store formative assessment results }\end{array}$ \\
\hline & & & $\begin{array}{l}\text { Level 2. Use of software and technical facilities to } \\
\text { analyze formative assessment results and update } \\
\text { and monitor pupils' progress. }\end{array}$ \\
\hline & & & $\begin{array}{l}\text { Level 3. Share, guide other students how to store } \\
\text { and analyze exam questions and exam results from } \\
\text { technological media. }\end{array}$ \\
\hline & & \multirow{3}{*}{$\begin{array}{l}\text { Use appropriate } \\
\text { methods to inform } \\
\text { pupils and related } \\
\text { persons about the } \\
\text { results of the } \\
\text { formative } \\
\text { assessment and use } \\
\text { the results of testing } \\
\text { and assessment to } \\
\text { adjust teaching and } \\
\text { educational } \\
\text { activities. }\end{array}$} & $\begin{array}{l}\text { Level 1. Evaluate and comment accurately on pupils' } \\
\text { formative assessment results }\end{array}$ \\
\hline & & & $\begin{array}{l}\text { Level 2. Promptly report scores (or comments) with } \\
\text { appropriate comments about strengths and } \\
\text { shortcomings of each pupil. }\end{array}$ \\
\hline & & & $\begin{array}{l}\text { Level 3. Propose measures to adjust the teaching } \\
\text { and learning process after the testing results are } \\
\text { available. Share and guide other students to discuss } \\
\text { and propose measures to adjust the process of } \\
\text { teaching mathematics in primary schools }\end{array}$ \\
\hline
\end{tabular}

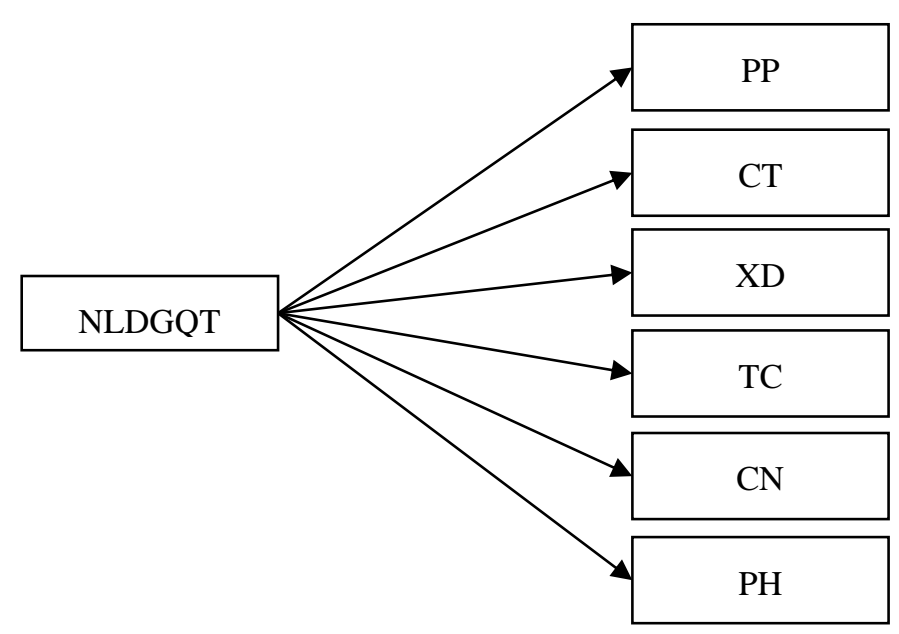

FIGURE 1. Components of formative assessment capacity in teaching primary Mathematics

NLDGQT: Capacity of formative assessment; PP: Capacity showing the understandings about methods, forms and formative assessment instruments in teaching primary Mathematics; CT: Capacity showing the understandings about how to use the formative assessment results in teaching primary Mathematics; XD: Capacity to develop the formative assessment plans ensuring the publicity, objectivity, accuracy, comprehensiveness and fairness; TC: Capacity to organize the formative assessment in teaching primary Mathematics; CN: Capacity to use information technology to support the formative assessment in teaching primary Mathematics; $\mathrm{PH}$ : Capacity to use conformable methods in responding formative assessment results to pupils 
and relevant parties, and in using assessment results to adjust teaching and educational activities.

\section{Sampling and data}

The samples are selected based on the criteria as being students with major in primary education of universities in Vietnam who have had enough basic knowledge and learned assessment knowledge in teaching or assessment in education as well as been equipped with sufficient knowledge and skills on formative assessment in teaching primary Mathematics to precisely determine the capacity of formative assessment in teaching Mathematics by students with major in primary education. The selected samples of the survey are the 3rd and 4th-year students the who have completed the module of Assessment in education and participated in visiting for practice and practicing activities in general school. There are 579 students from 11 universities in Vietnam who participated in answering the Questionnaire, including: Da Nang University; Can Tho University; Hung Vuong University; An Giang University; Dong Nai University; Sai Gon University; Hanoi Pedagogical University 2; Hanoi National University of Education; Vinh University; Dong Thap University; Hong Duc University with the number shown in Table 2. All surveyed and interviewed are informed about the content and purpose of the survey. The survey results are purely for research for this article and are kept confidential.

Table 2. Survey samples for the research at 11 Vietnamese universities

\begin{tabular}{ccc}
\hline No. & Name of Universities & Number of students \\
\hline & Hanoi Pedagogical & 70 \\
University 2 & \\
& Hanoi National & \\
& University of & 68 \\
2 & Education & \\
3 & Hung Vuong & 40 \\
4 & Da Nang & 50 \\
5 & Vinh & 50 \\
6 & Hong Duc & 39 \\
7 & Can Tho & 60 \\
8 & An Giang & 24 \\
9 & Dong Nai & 30 \\
10 & Sai Gon & 56 \\
11 & Dong Thap & 92 \\
\hline & Total & 579 \\
\hline
\end{tabular}

The samples were selected from three regions of Vietnam to ensure the representative of the sample, the distribution of research samples is shown in Figure 2.

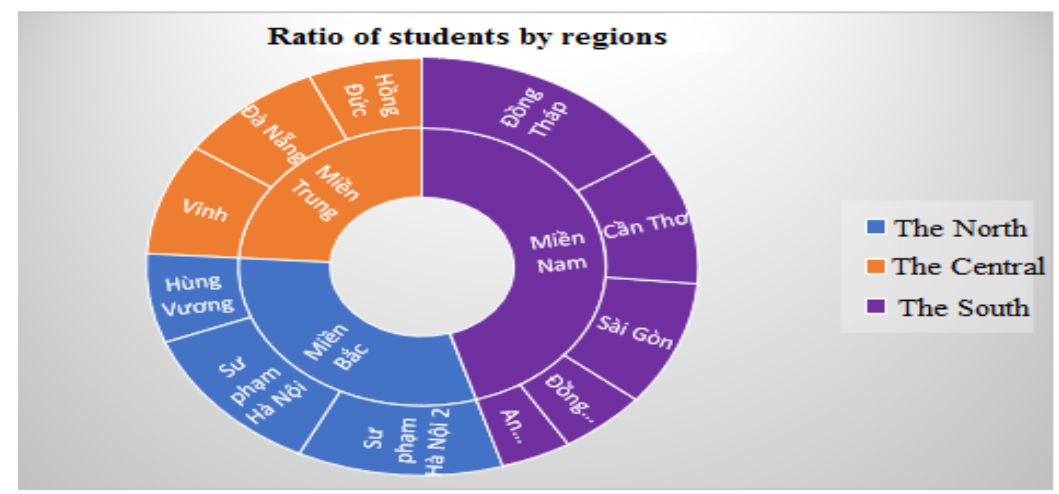

FIGURE 2. Number of research samples distributed by regions of Vietnam 
The distribution of male/female ratio is based on the current ratio of primary male/female teachers in Vietnam. The ratio of female teachers at primary schools in Vietnam at the end of April 2018 is 86\% (4997 female teachers/5817 total teachers) as announced by the Ministry of Education and Training(Moet.gov.vn, n.d.) (figure 3). In addition, the analysis indicates that the ratio of third-year students and fourth-year students in survey samples is appropriate, the research focuses mainly on the fourth-year students who have a longer internship period in primary schools compared to the third-year students, but thirdyear students have also completed the assessment part in the curriculum and also had time to visit for practice in primary schools. The ratio of third and fourth-year students is shown in Figure 4.

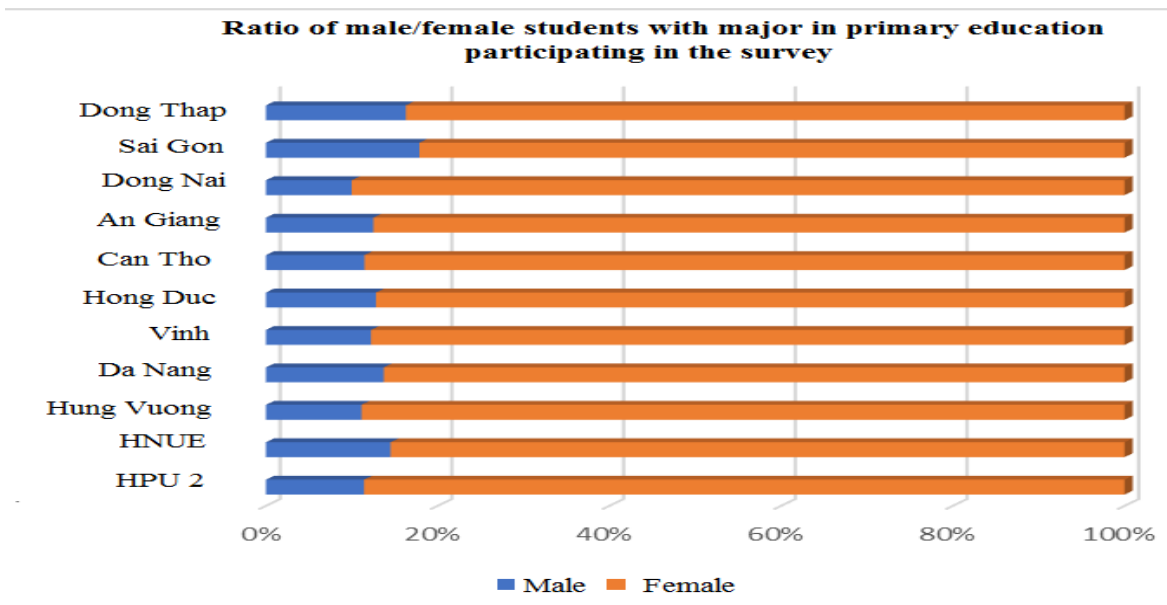

FİGURE 3. Ratio of male/female students with major in primary education participating in the survey

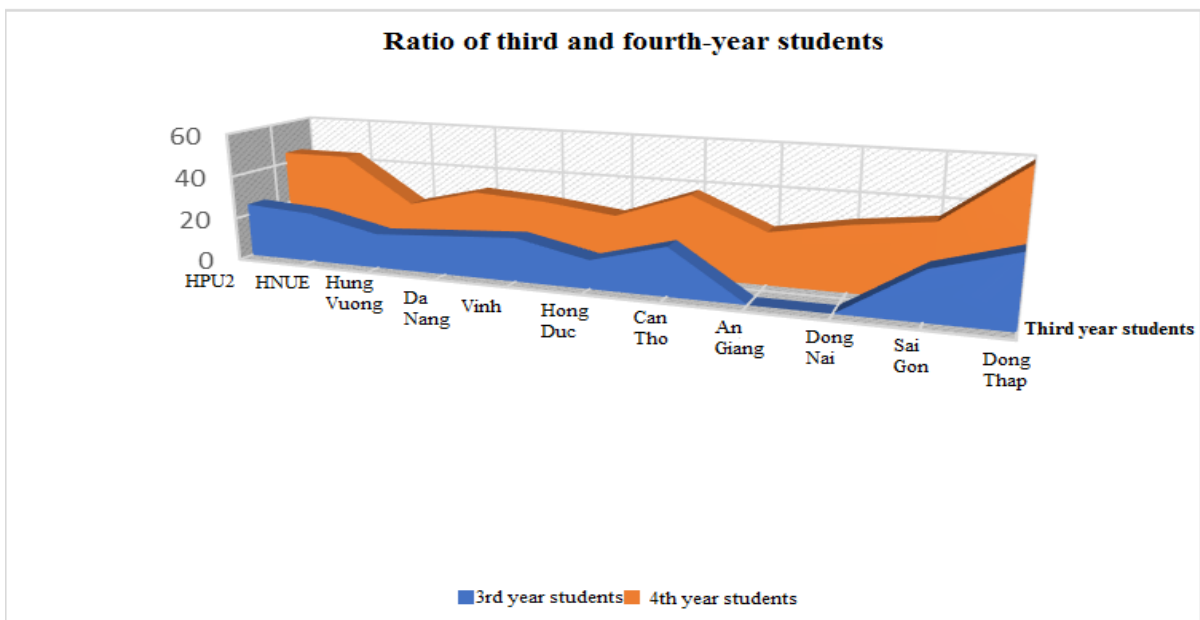

FIGURE 4. Ratio of third and fourth-year students participating in the survey

\section{Research Method}

The research uses the quantitative method and is conducted based on the design of the questionnaire and survey organization, data collection and analysis. The questionnaire consists of 25 observed variables on Capacity of formative assessment in teaching primary Mathematics, and is designed according to a 5-step scale from very good to not very good, corresponding to 5 options: Strongly agree; Agree; Neither agree nor disagree; Disagree; Strongly disagree. The results of quantitative study will describe the current situation of capacity of formative assessment in teaching Mathematics by students with major in primary education 


\section{RESULTS AND DISCUSSION}

Firstly, the research assessed capacity to "Demonstrate the understandings about methods, forms and instruments of formative assessment in teaching primary mathematics" of students in Vietnamese universities by separating 3 observed variables PP2, PP3, and PP4 to analyze the remaining variables for the component of formative assessment capacity PP (Figure 5). The results show that students have initially grasped the method of formative assessment for the primary mathematics, but, the results also show that more than 100 students do not grasp well about this part, which is entirely appropriate for the result of students answering PP5, which means that students who have not understood the method and form of formative assessment for the primary mathematics cannot understand the combination of formative assessment methods in teaching Mathematics.

Table 3. Observed variables of formative assessment factors in teaching primary Mathematics by students

\begin{tabular}{|c|c|c|c|}
\hline Factors & $\begin{array}{l}\text { Observed } \\
\text { variables }\end{array}$ & & Variable description \\
\hline \multirow[t]{9}{*}{ PP } & \multirow{9}{*}{$\begin{array}{l}\text { PP1; PP2, } \\
\text { PP3; PP4, } \\
\text { PP5; PP6; } \\
\text { PP7; PP8, } \\
\text { PP9 }\end{array}$} & PP1 & $\begin{array}{l}\text { I can understand about suitable methods and forms of } \\
\text { formative assessment in teaching primary Mathematics }\end{array}$ \\
\hline & & PP2 & I know How to use objective multiple-choice questions \\
\hline & & PP3 & I know How to observe behaviors and give comments \\
\hline & & PP4 & I know the Method of task assignment forms to pupils \\
\hline & & PP5 & $\begin{array}{l}\text { I know how to use and combine various methods and forms of } \\
\text { formative assessment that are appropriate for the } \\
\text { characteristics of mathematics and primary pupils. }\end{array}$ \\
\hline & & PP6 & $\begin{array}{l}\text { Have appropriate strategies of formative assessment for } \\
\text { primary pupils to actively participate in the assessment } \\
\text { process. }\end{array}$ \\
\hline & & PP7 & I understand the characteristics of primary students \\
\hline & & PP8 & I understand the Mathematics program in primary schools \\
\hline & & PP9 & $\begin{array}{l}\text { I provide ways to attract students to participate in the } \\
\text { formative assessment }\end{array}$ \\
\hline \multirow[t]{3}{*}{ CT } & \multirow[t]{3}{*}{$\begin{array}{l}\text { CT1, CT2, } \\
\text { CT3 }\end{array}$} & CT1 & $\begin{array}{l}\text { I respond the results of the formative assessment that are } \\
\text { appropriate for primary pupils, their parents (or sponsors) and } \\
\text { the school. }\end{array}$ \\
\hline & & CT2 & $\begin{array}{l}\text { I use the results of the formative assessment for the purpose of } \\
\text { developing qualities and capacities of primary pupils. }\end{array}$ \\
\hline & & CT3 & $\begin{array}{l}\text { I share your knowledge of methods, form of formative } \\
\text { assessment and response methods with other students }\end{array}$ \\
\hline \multirow[t]{3}{*}{$\mathrm{XD}$} & \multirow[t]{3}{*}{$\begin{array}{l}\text { XD1, XD2, } \\
\quad \text { XD3 }\end{array}$} & XD1 & $\begin{array}{l}\text { I can develop a formative assessment plan that is aligned with } \\
\text { the teaching plan and mathematics curriculum at primary } \\
\text { schools. }\end{array}$ \\
\hline & & $\mathrm{XD} 2$ & $\begin{array}{l}\text { I formative assessment plan uses methods and forms of } \\
\text { assessment appropriate to the characteristics of primary } \\
\text { mathematics, primary pupils, and the assessment purposes. }\end{array}$ \\
\hline & & XD3 & $\begin{array}{l}\text { My formative assessment plan can demonstrate the methods } \\
\text { and forms for assessing pupils in the direction of approach to } \\
\text { mathematics learning capacity }\end{array}$ \\
\hline
\end{tabular}


Table 3. Continued.

\begin{tabular}{|c|c|c|c|}
\hline Factors & $\begin{array}{l}\text { Observed } \\
\text { variables }\end{array}$ & & Variable description \\
\hline \multirow[t]{3}{*}{$\mathrm{TC}$} & $\begin{array}{l}\text { TC1; TC2; } \\
\quad \text { TC3 }\end{array}$ & TC1 & $\begin{array}{l}\text { I organize the formative assessment in teaching primary } \\
\text { mathematics on your own that ensure the content and form in } \\
\text { accordance with the plan developed }\end{array}$ \\
\hline & & $\mathrm{TC} 2$ & $\begin{array}{l}\text { I can organize a flexible formative assessment that ensures the } \\
\text { publicity, objectivity, accuracy, comprehensiveness and fairness. }\end{array}$ \\
\hline & & $\mathrm{TC} 3$ & $\begin{array}{l}\text { I can co-ordinate and share with other students about the } \\
\text { formative assessment activities during the practice and internship } \\
\text { process, and coordinate to organize the flexible student formative } \\
\text { assessment process while ensuring the publicity, objectivity and } \\
\text { accuracy, comprehensiveness and fairness. }\end{array}$ \\
\hline \multirow[t]{3}{*}{$\mathrm{XD}$} & $\begin{array}{l}\text { XD1; XD2; } \\
\quad \text { XD3 }\end{array}$ & SD1 & $\begin{array}{l}\text { I use software and technical facilities to store the results of } \\
\text { formative assessment }\end{array}$ \\
\hline & & $\mathrm{SD} 2$ & $\begin{array}{l}\text { I use the software and technical facilities to analyze the results of } \\
\text { formative assessment and update, track the pupil's progress. }\end{array}$ \\
\hline & & SD3 & $\begin{array}{l}\text { I share, guide other students how to store and analyze exam } \\
\text { questions and exam results from technological facilities. }\end{array}$ \\
\hline \multirow[t]{3}{*}{$\mathrm{CN}$} & $\begin{array}{l}\text { CN1; CN2; } \\
\quad \text { CN3 }\end{array}$ & CN1 & $\begin{array}{l}\text { I use software and technical facilities to store } \\
\text { the results of formative assessment }\end{array}$ \\
\hline & & CN2 & $\begin{array}{l}\text { I use the software and technical facilities to analyze the results of } \\
\text { formative assessment and update, track the pupil's progress }\end{array}$ \\
\hline & & $\mathrm{CN} 3$ & $\begin{array}{l}\text { I share, guide other students how to store and analyze exam } \\
\text { questions and exam results from technological facilities. }\end{array}$ \\
\hline \multirow[t]{4}{*}{$\mathrm{PH}$} & $\begin{array}{l}\text { PH1; PH2; } \\
\text { PH3; PH4 }\end{array}$ & PH1 & $\begin{array}{l}\text { I assess and comment accurately on the results of the pupil's } \\
\text { formative assessment }\end{array}$ \\
\hline & & $\mathrm{PH} 2$ & $\begin{array}{l}\text { I promptly notify the results (or comments) with appropriate } \\
\text { comments about the strengths and weak points to be made good } \\
\text { of each pupil. }\end{array}$ \\
\hline & & PH3 & $\begin{array}{l}\text { I propose measures to adjust the teaching and learning process } \\
\text { after the exam results are available. }\end{array}$ \\
\hline & & $\mathrm{PH} 4$ & $\begin{array}{l}\text { I can share, guide other students to discuss and propose } \\
\text { measures to adjust the process of teaching primary mathematics. }\end{array}$ \\
\hline
\end{tabular}

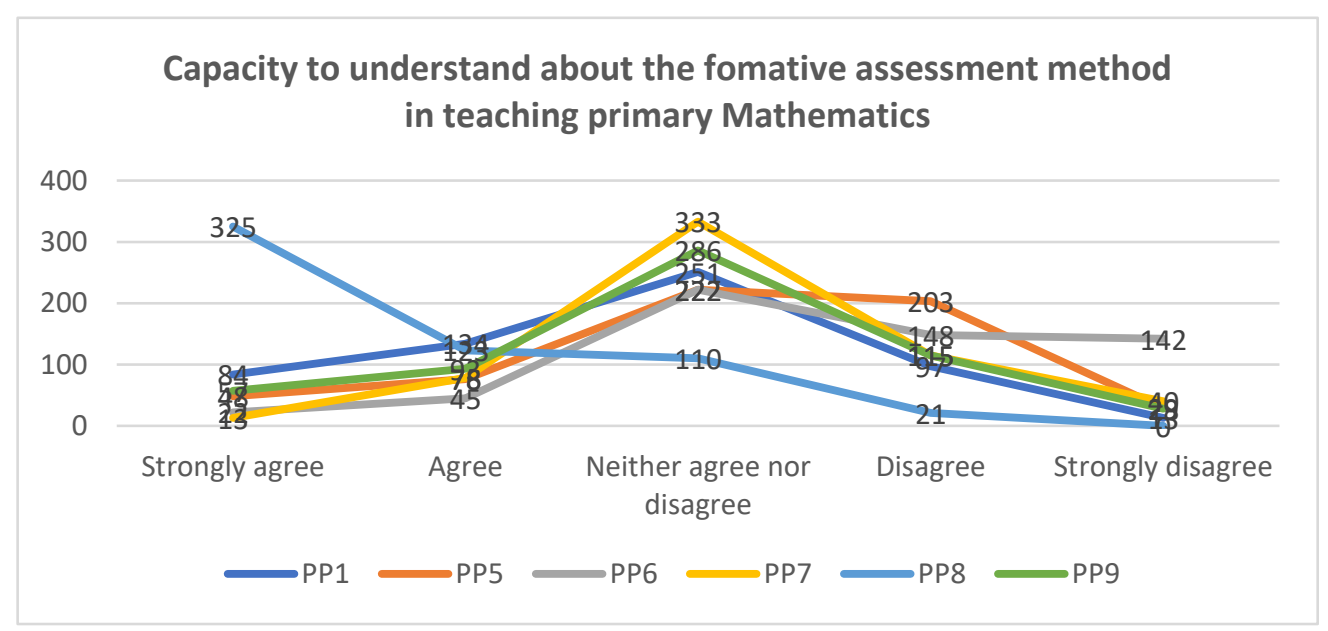

FIGURE 5. Results of surveying the capacity to demonstrate the understandings about methods, forms and instruments of testing and assessment

PP7 and PP8 are highly appreciated by students, meaning that students can understand the characteristics of primary students and the primary mathematics curriculum, but the understanding extent about assessment methods (PP1) ) is not good, mainly at the normal 
extent, therefore students have not provided measures to attract students in their assessment process, and the survey results on PP6 are not high, the number of students at good level and above only accounts for $14 \%$, the number of students at normal level is $40 \%$ and $56 \%$ of students have not provided a strategy to attract students to participate in the formative assessment. Conducting to analyze survey results for the remaining three observed variables in PP factors including PP2, PP3, and PP4 which are in-depth observed variables about methods of formative assessment in teaching primary mathematics (Figure 6).

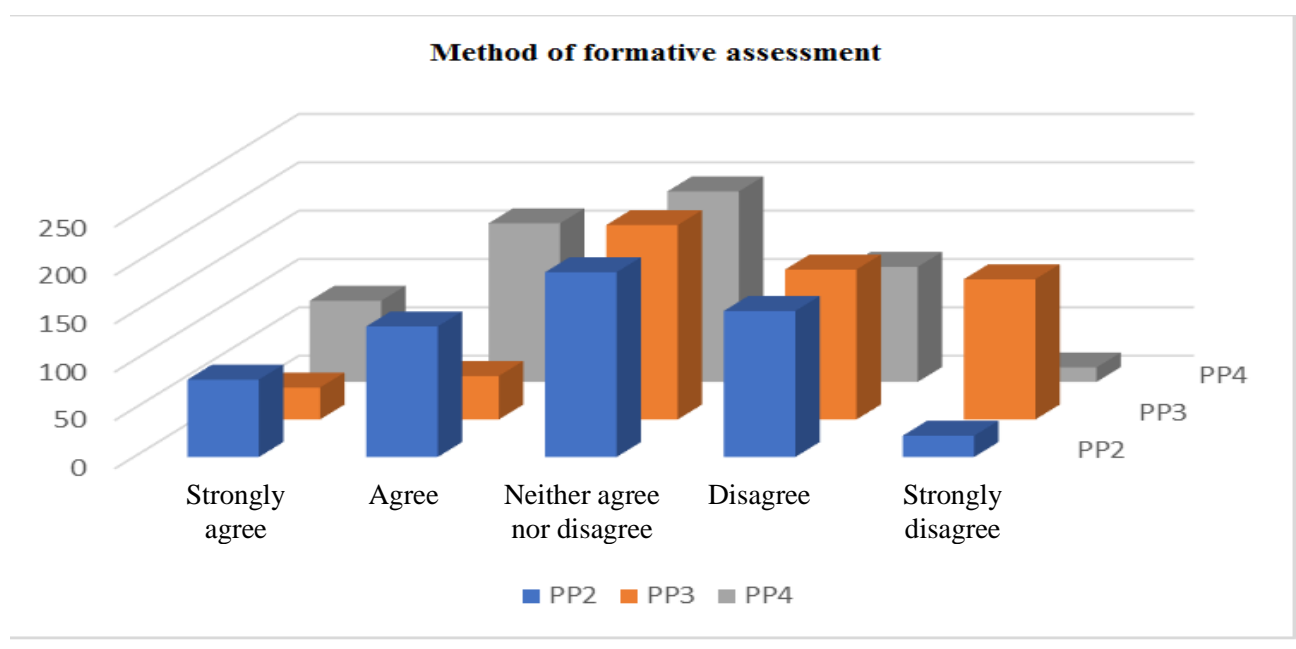

FIGURE 6. Result of student's responses on the understanding about the method of formative assessment in teaching primary mathematics

Figure 6 shows that students have not had a good understanding of the three typical methods of formative assessment in teaching primary mathematics, the number of students who have a good understanding of the method using objective multiple-choice questions and the method of using task assignment forms accounts more, many students have not grasped well the knowledge of methods of observing students' behaviors, thereby making comments to pupils right in the teaching process (up to $52 \%$ of students rated themselves as not well observe pupil's behaviors)

The research further analyzes the survey results on the capacity to understand the methods of using formative assessment results in teaching primary mathematics (Figure 7). The research result showing that students have not had good knowledge about how to use the formative assessment in teaching primary mathematics, especially in the process of studying in class as well as visiting for practice and practicing in general schools, students who are not good in knowledge cannot share their experience about using the formative assessment results in teaching math to each other, this is very detrimental to students after graduating because the period of studying at the university is to create fundamental knowledge, the period of visiting for practice and practicing is the testing one, bringing knowledge, skills to practice at class. However, students still have not had enough fundamental knowledge, understandings about using formative assessment as well as together discussing and sharing experiences. 


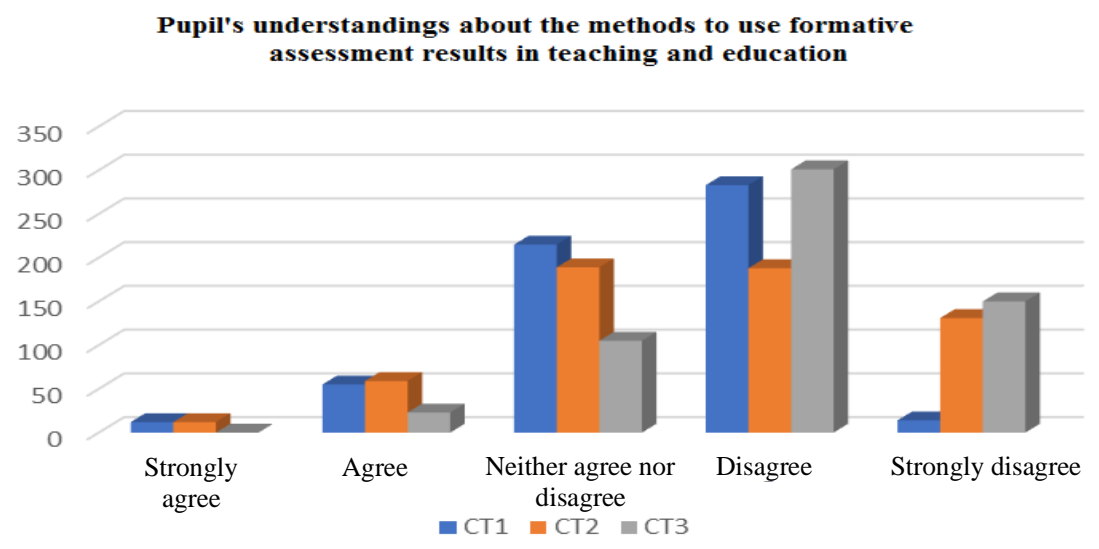

FIGURE 7. Result of student's responses on the understanding about methods to use formative assessment results in teaching primary mathematics

Regarding the capacity to develop a formative assessment plan to ensure the publicity, objectivity, accuracy, comprehensiveness and fairness (Figure 8) and the capacity to organize the formative assessment in teaching primary mathematics by the students (Figure 9), the research shows that students can develop a plan appropriate to the characteristics of the learners (73.5\% of students achieve average level or above) and can select an appropriate method of formative assessment (77.9\% of students achieve average level or above) and over $86.5 \%$ of students achieve average level or above in developing a formative assessment plan in teaching primary mathematics in the direction of capacity approach. Besides, students can organize formative assessment activities in teaching primary mathematics $185 \%$ of students achieve average level or above); $78 \%$ of students can flexibly organize stages of the formative assessment at an average level or above; Especially, 93.6\% of students achieve average level or above in being able to share with their classmates how to organize the formative assessment in teaching primary mathematics. Similar to the above two capacities, the capacity to use information technology to support the formative assessment in teaching primary mathematics by students achieves at a high level (Figure 10), with $93.4 \%$ of students achieving average level or above can use information technology to store assessment results (of which $59.7 \%$ of students are at a good level or above), but the number of students achieving average level or above in using software that supports to analyze assessment results is quite low $(12.9 \%)$, therefore, only $18.6 \%$ of students can share with their classmates about using information technology to support the formative assessment in teaching primary mathematics.

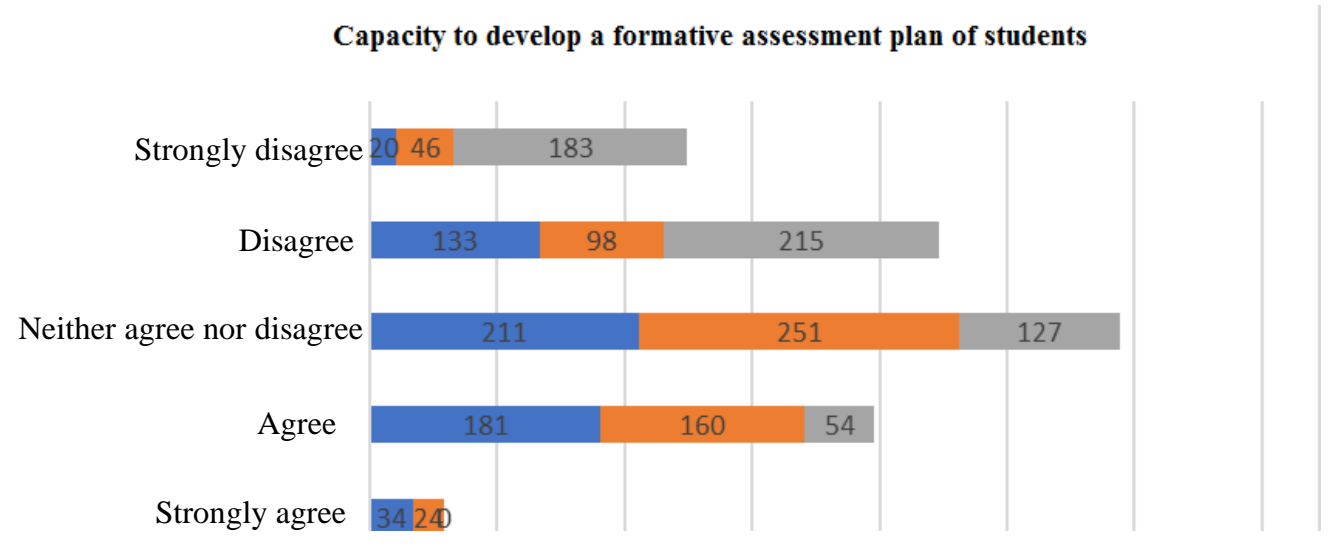

FIGURE 8. Result of student's responses on the development of a formative assessment planin teaching primary mathematics 


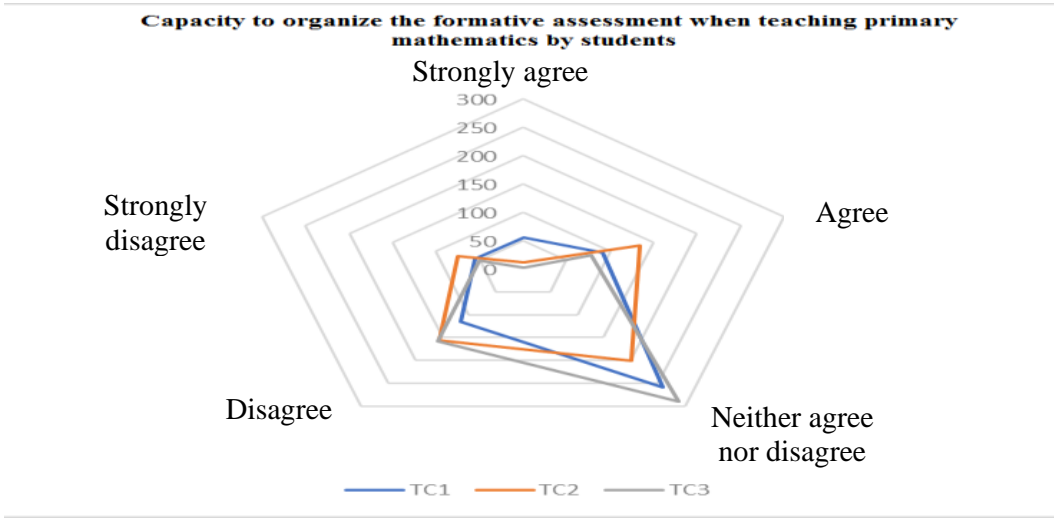

FIGURE 9. Results of students' responses on the results of organizing formative assessmentin teaching primary mathematics

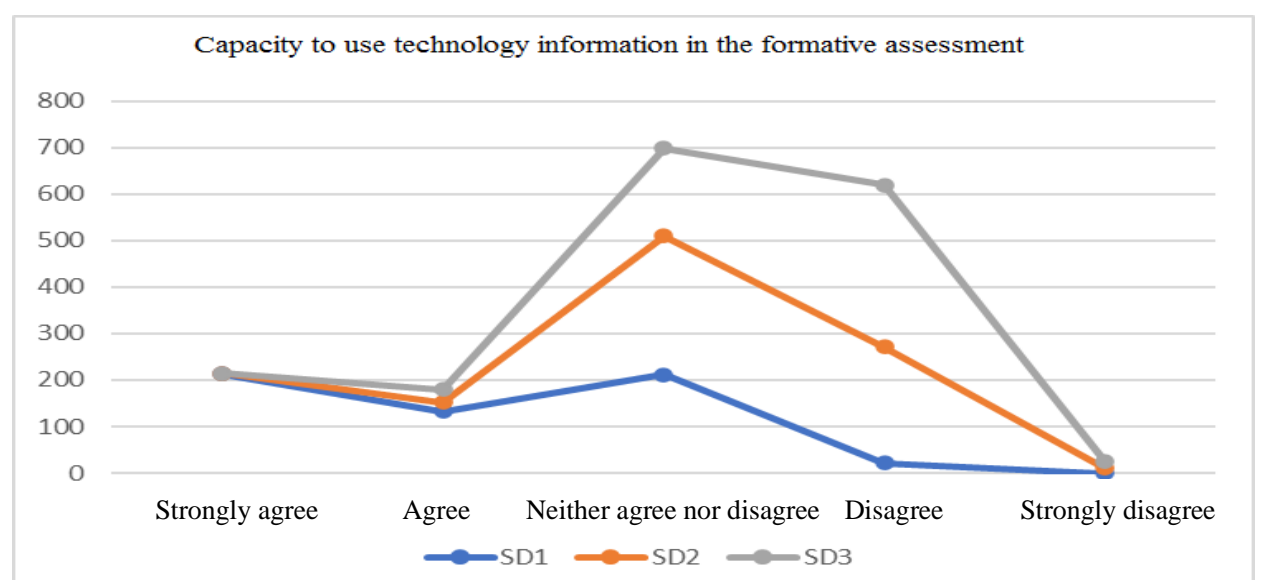

FIGURE 10. Result of student's responses on the use of information technology to support the formative assessment in teaching primary mathematics

The results of surveying the three above-mentioned capacity components seem to contradict the results of assessing the first capacity component about an understanding of methods and forms of formative assessment. However, if continuing to analyze the results of assessing the final formative assessment capacity on the use of appropriate methods to inform the result of the formative assessment to pupils and relevant parties and the use of assessment results to adjust activities of teaching primary mathematics, a logical relationship in the assessment results will be indicated. Such relationship is that students are capable of developing a formative assessment plan; organizing the formative assessments and basically capable of using information technology to support the formative assessments, but, because students do not know much about methods and forms of assessment, especially the typical methods of formative assessment in teaching primary mathematics the design of assessment instruments is not good and the capacity to use formative assessment results is also not good, then the collection of formative assessment information is not good and leads to students having difficulty in accurately assessing pupil's' capacity (only $52.1 \%$ of students achieve the average level or above, of which $21 \%$ achieve the good level or above); $64 \%$ of students can comment the lesson and advantages and disadvantages of pupils and only $22.4 \%$ of students can well share with their classmates about responses to pupils and pupil's parents (or sponsors). 
Using appropriate methods to inform the result of the formative assessment to pupils and relevant parties and using assessment results to adjust activities of teaching primary mathematics

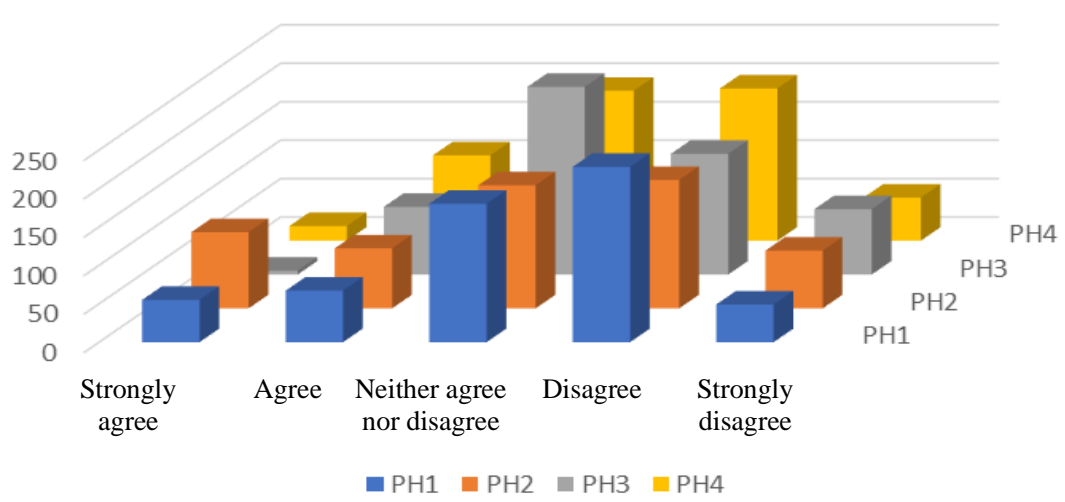

FIGURE 11. Result of student's responses on the use of appropriate methods to inform the result of the formative assessment to pupils and relevant parties and the use of assessment results to adjust activities of teaching primary mathematics

\section{SUGGESTIONS}

The research shows that the capacity of formative assessment in teaching mathematics in primary schools of 11 universities typical for the three regions of Vietnam is still limited, especially in the capacity to know methods, tools and forms of formative assessment in teaching mathematics in primary schools; ability to understand the use of formative assessment results in teaching primary mathematics; ability to use the appropriate method to inform students and stakeholders of the formative assessment results and at the same time use the assessment results to adjust students' mathematics teaching activities in primary schools. With this limitation, if the student is not fostered and directed in time, it will greatly affect the effectiveness of the student's assessment process after graduation and the formative assessment probably will not be as effective as the research results of Fiza Rashid-Doubell and Robin 0 'Sullivan on the opposite effect of formative assessment, but with different causes, if Fiza Rashid-Doubell and Robin O' Sullivan think that the formative assessment is not successful and effective due to students, in this research, it will be the opposite because the teachers are not competent enough to assess the process (Fiza Rashid-Doubell, Robin O' Sullivan, 2017). Because the capacity of formative assessment is an important capacity in the teaching process, the research proposes several measures to help foster the capacity of formative assessment in teaching primary mathematics for students in universities in Vietnam, including:

Firstly, providing sufficient knowledge on formative assessment in teaching mathematics in primary schools and initially train the capacity of formative assessment in teaching through analysis of short videos on teaching mathematics in primary schools: The structure of the training program of primary education teachers in universities in Vietnam, the module Methods of Teaching Mathematics in Primary Schools is compulsory, so whether or not students can learn the knowledge about formative assessment in teaching mathematics in primary schools, it is necessary to integrate and foster more knowledge and train Formative assessment skills during learning the module Methods of Teaching Mathematics in Primary Schools. To achieve this, it is necessary to guide students to learn knowledge about methods, forms, and tools for process evaluation. Besides, it is necessary to organize for students to develop assessment plans, select methods, forms and design process assessment tools right in the process of learning module Methods of Teaching Mathematics in Primary Schools. Using the method of consulting experts (who are direct trainers; primary teachers; classmates) to get suggestions to improve their understanding of formative assessment in teaching mathematics in primary schools.

Secondly, organizing students to train the capacity of formative assessment in teaching Mathematics in the assumed primary-school class: Through the training of teaching Mathematics 
in the assumed class (students in the same class plays the part of primary pupils), teaching and fostering the ability to observe the behavior of assumed students to assess the process through observing human behavior, commenting on the students' results of learning mathematics, and at the same time, training students to make a teaching plan which includes a formative assessment plan and training of students to organize the formative assessment according to the plan built on the assumed class. Although the training of assessing the process has objects that are not close to the real objects of primary pupils, the objects of an assumed class are students specialized in primary education, it will be advantageous that they will make the most of the experiences that we have learned from materials, teachers, and friends to conduct assessment and examination activities simulated according to primary students. This training can be done in a 3-step process including: (i) Organizing students to study sample Video of teaching Mathematics and observing Mathematics learning behavior of students in Video; (ii) Organizing students to train teaching and assessing Mathematics in practical periods in the module Methods of Advanced Primary Mathematics Teaching step by step. (iii) Self-commenting, friends' comment, and especially the teachers of the module Methods of Advanced Primary Mathematics Teaching will observe, comment and give suggestions to the students. This training will help students deepen their knowledge and understanding about the formative assessment, plan development; organize formative assessment through assumed lessons.

Thirdly, organizing students to experience the formative assessment in teaching Mathematics through the process of pedagogical visits and internships in primary schools. In Vietnam, students will undergo at least a visit and an internship in high schools, this is the time when students practice in the real environment under the guidance of primary teachers before graduating. Adding the training of formative assessment skills in high schools; Each student must approach and practice the forms of formative assessment in teaching Mathematics in primary schools under the supervision of teachers. Through the apprenticeship activity, students will experience the situation and gain experience for themselves before graduation, ensure good conditions for students to conduct teaching and formative assessment in teaching mathematics in primary school after graduation.

\section{CONCLUSIONS}

The issue of measurement and assessment in education always attracts the attention of scientists around the world as well as in Vietnam. Besides renovating the contents, methods and forms of teaching, the issue of assessing learners is also of interest to scientists; However, an overview of the research history shows that at present, there is not any domestic and foreign work on training the capacity of formative assessment in teaching primary Mathematics for students majored in primary education.

Assessment is one of the most important stages in the teaching process, helping students see their strengths and weaknesses in learning to continue to rise, helping teachers see the advantages and disadvantages of their teaching to constantly improve. Assessments also make an important contribution to training pupils with good qualities such as academic enthusiasm, effort, awareness, humility, self-respect, honesty, etc. contributing significantly in adjusting the teaching attitude of teachers and learning attitudes of students.

Assessments can be considered as the end of the learning process, reflecting the results and quality of teaching, but at the same time the assessment is considered as a lever of the learning process, assessment will help teachers adjust your teaching activities accordingly; Students can adjust the activity accordingly.

The issue of measurement and assessment in education always attracts the attention of scientists in the world. For many years, scientists have focused on deep research on Measurement theory; concepts, roles, functions and assessment methods to gradually improve the theoretical system of learner assessment.

The research was conducted with 579 representative samples of 11 universities in Vietnam with a bachelor's degree in primary education. From the results of the data analysis, the research shows that the capacity of formative assessment in teaching primary mathematics of universities in Vietnam is limited, knowledge of methods, forms and tools of formative 
assessment and how to use formative assessment results is ineffectively and inadequately; capacity to observe pupils 'behaviors to respond to learners as well as the capacity to use appropriate feedback methods of pupils' learning results from which devise strategies to adjust bad teaching methods. From the survey results, the research proposes measures to develop the capacity of formative assessment in teaching primary mathematics of students, including: Providing sufficient knowledge of process assessment in teaching mathematics in primary schools and initially a training capacity of formative assessment in teaching through analysis of short videos on teaching mathematics in primary schools; organizing students to practice the capacity of formative assessment in teaching Mathematics in assumed primary classes; organizing students to experience formative assessment in teaching Mathematics through pedagogical visit and internship in primary schools.

\section{REFERENCES}

Andrade, H. L., \& J.Cizel, G. (2013). Handbook of Formative assessment. In Journal of Chemical Information and Modeling (Vol. 53, Issue 9). https://doi.org/10.1017/CB09781107415324.004

Barry J. Zimmerman. (1990). Goal Setting and Self-Efficacy During Self-Regulated Learning. Educational Psychologist, 25(1), 3-17. https://doi.org/10.1207/s15326985ep2501

Bourke, R., \& Mentis, M. (2014). An assessment framework for inclusive education: integrating assessment approaches. Assessment in Education: Principles, Policy and Practice, 21(4), 384-397. https://doi.org/10.1080/0969594X.2014.888332

Chung, P. X. (2012). Prepare for students of Mathematics pedagogy in universities to conduct activities to evaluate the learning results of high school students. Vinh University, Vietnam.

Cook, A. (2001). Assessing the use of flexible assessment. Assessment and Evaluation in Higher Education, 26(6), 539-549. https://doi.org/10.1080/02602930120093878

Dinh, P. N. (2016). Methods of teaching Mathematics in elementary schools (episode 2). Publisher of Hanoi University of Education, Vietnam.

Fiza Rashid-Doubell, Robin O' Sullivan, T. D. and K. E. (2017). Using formative assessment to stimulate reflection and ownership amongst academically weak first-year undergraduate medical students. In Using data to inform strategies to promote student retention and success (Issue January 2013, pp. 80-83).

Garrett, J. M., \& Camper, J. M. (2015). Formative Assessment as an Effective Leadership Learning Tool. 145, 97-106. https://doi.org/10.1002/yd

Hoa, P. D. (2012). Evaluate educational results in primary schools. Publisher of Hue University of Education, Vietnam.

Hop, N. H. (2015). A Guide to Primary School Student Assessment. Hanoi National University Publisher, Vietnam.

Khanh, N. C. (2004). Measuring measurement in social sciences: process, technique, design, standardization of measuring tools. National Political Publishing House of Vietnam.

Kibble, J. (2007). Use of unsupervised online quizzes as formative assessment in a medical physiology course: Effects of incentives on student participation and performance. American Journal of Physiology - Advances in Physiology Education, 31(3), 253-260. https://doi.org/10.1152/advan.00027.2007

Kizlik, B. (2012). Measurementandevaluationineducationnotes2. 1-43.

Marks, I. (2015). Formative ( Classroom ) Assessment Techniques. 4(1), 46-50. https://doi.org/10.1515/atd-2015-0012

Moet.gov.vn. (n.d.). https://moet.gov.vn/thong-ke/Pages/thong-ke-giao-duc-tieu-hoc.aspx?ItemID=5392.

Pham Dinh Thuc. (2007). Teaching Maths in elementary school by assignments. Vietnam Education Publishing House.

Pham, T. Van, Nghiem, T. T., Nguyen, L. M. T., Mai, T. X., \& Tran, T. (2019). Exploring Key Competencies of Mid-Level Academic Managers in Higher Education in Vietnam. Sustainability, 11(23), 6818. https://doi.org/10.3390/su11236818

Phuong Thao, T. T., Thai, L. D., Thanh, H. T., Tran, T., Tuyet Trinh, L. T., \& Vuong, Q. H. (2019). Mobile learning for high-school mathematics as a path to better sustainability in a fast-changing society: An exploratory study from Vietnam. Problems and Perspectives in Management, 17(2), 392-403. https://doi.org/10.21511/ppm.17(2).2019.30

Pryor, J. (2004). Pedagogies of in / equity: Formative assessment / Assessment for Learning.

Sainsbury, M., \& Benton, T. (2011). Designing a formative e-assessment: Latent class analysis of early reading skills. British Journal of Educational Technology, 42(3), 500-514. 
https://doi.org/10.1111/j.1467-8535.2009.01044.x

Teacher, C. for Q. (2005). Georgia Extended Framework for Teaching.

Tho, C. C. (2014). Training the ability to observe and evaluate student behavior for pedagogical students. Journal of Science - Ha Noi University of Education, Vietnam, 59(2), 2014.

Tran, T., Le, T. T. H., Nguyen, T. T., Pham, A. G., Vu, T. H., Nguyen, M. H., Vuong, H. M., Vuong, T. T., Hoang, P. H., Ho, M. T., \& Vuong, Q. H. (2019). The relationship between birth order, sex, home scholarly culture and youths' reading practices in promoting lifelong learning for sustainable development in Vietnam. Sustainability (Switzerland), 11(16). https://doi.org/10.3390/su11164389

Tran, T., Nguyen, T. T. T., Le, T. T. T., \& Phan, T. A. (2019). Slow learners in mathematics classes: the experience of Vietnamese primary education. Education 3-13, $0(0), 1-17$. https://doi.org/10.1080/03004279.2019.1633375

Tran, T., Pham, T. X., \& Vu, T. T.-T. (2020). E-Class Education Model in Modern Educational TechnologyBased Approach. In Intelligent Computing Paradigm and Cutting-edge Technologies (Issue Icicct, pp. 405-416). Springer. https://doi.org/10.1007/978-3-030-38501-9_37

Trinh, L. T. T. (2013). Some activities form the capacity to assess students' learning outcomes in Math for primary education students. Vietnam Journal of Education, 323, 39-40. https://doi.org/10.11113/jt.v56.60

Vu Quoc Chung, Lai, D. T., Dat, D. T., Lan, T. N., Quang, N. H., \& Son, L. N. (2005). Methods of teaching Mathematics in elementary schools. Vietnam Education Publishing House.

Yorke, M. (2003). Formative assessment in higher education: Moves towards theory and the enhancement of pedagogic practice. Higher Education, 45(4), 477-501. https://doi.org/10.1023/A:1023967026413 